MT-DP - 2012/ 3

\title{
Tax Morale and Tax Evasion: Social Preferences and Bounded Rationality
}

ZSOMBOR Z. MÉDER - ANDRÁS SIMONOVITS -

- JÁNOS VINCZE 
Discussion papers

MT-DP - 2012/3

Institute of Economics, Research Centre for Economic and Regional Studies,

Hungarian Academy of Sciences

KTI/ IE Discussion Papers are circulated to promote discussion and provoque comments. Any references to discussion papers should clearly state that the paper is preliminary. Materials published in this series may subject to further publication.

Tax Morale and Tax Evasion: Social Preferences and Bounded Rationality

Authors:

Zsombor Z. Méder

Maastricht University

Department of Economics

email: z.meder@maastrichtuniversity.nl

András Simonovits

Hungarian Academy of Sciences, Institute of Economics

Budapest University of Technology and Economics

Institute of Mathematics

Central European University, Department of Economics email: simonov@econ.core.hu

János Vincze

Corvinus University of Budapest,

Hungarian Academy of Sciences, Institute of Economics

email: janos.vincze@uni-corvinus.hu

J anuary 2012

ISBN 978-615-5024-94-8

ISSN $1785377 \mathrm{X}$ 


\title{
Tax Morale and Tax Evasion: Social Preferences and Bounded Rationality
}

\author{
ZSOMBOR Z. MÉDER - ANDRÁS SIMONOVITS - JÁNOS VINCZE
}

\begin{abstract}
We study a family of models of tax evasion, where a flat-rate tax finances only the provision of public goods, neglecting audits and wage differences. We focus on the comparison of two modeling approaches. The first is based on optimizing agents, who are endowed with social preferences, their utility being the sum of private consumption and moral utility. The second approach involves agents acting according to simple heuristics. We find that while we encounter the traditionally shaped Laffer-curve in the optimizing model, the heuristics models exhibit (linearly) increasing Laffer-curves. This difference is related to a peculiar type of behavior emerging within the heuristics based approach: a number of agents lurk in a moral state of limbo, alternating between altruism and selfishness.
\end{abstract}

Keywords: tax evasion, tax morale, agent-based simulation,

JEL classification: H26 


\section{Adómorál és adócsalás}

\section{MÉDER ZSOMBOR Z. - SIMONOVITS ANDRÁS - VINCZE JÁNOS}

\section{Összefoglaló}

Egy olyan adócsalásmodell-családot vizsgálunk, amelyben az egykulcsos adó kizárólag a közjavakat finanszírozza. Két megközelítés összehasonlítására összpontosítunk. Az elsőben minden dolgozó jövedelme azonos, és ebból minden évben annyit vall be, amennyi maximalizálja a nála maradó jövedelemből fedezhető fogyasztás nyújtotta hasznosság és a jövedelembevallásból fakadó hasznosság összegét. A második hasznosság három tényező szorzata: a dolgozó exogén adómorálja, a környezetében előző évben megfigyelt átlagos jövedelembevallás és saját bevallásából fakadó endogén hasznossága. A második megközelítésben az ágensek egyszerü heurisztikák szerint cselekszenek. Míg az optimalizáló modellben hagyományos Laffer-görbékkel találkozunk, addig a heurisztikán alapuló modellekben (lineárisan) növekvő Laffergörbék jönnek létre. E különbség oka, hogy a heurisztikus alapú modellben egy sajátos fajta viselkedés jelentkezik: számos ágens ingatag helyzetbe kerül, amelyben altruizmus és önzés között ingadozik.

Tárgyszavak: adócsalás, adómorál, ágens alapú modell

JEL kód: H26 


\title{
Tax Morale and Tax Evasion: Social Preferences and Bounded Rationality
}

\author{
Zsombor Z. Méder ${ }^{\mathrm{a}, *}$, András Simonovits ${ }^{\mathrm{b}, \mathrm{c}, \mathrm{d}}$, János Vincze ${ }^{\mathrm{b}, \mathrm{e}}$ \\ ${ }^{a}$ Maastricht University, Department of Economics, P.O.Box 616, 6200 MD Maastricht, The Netherlands \\ ${ }^{b}$ Hungarian Academy of Sciences, Institute of Economics, Budaörsi út 45, 1112 Budapest, Hungary \\ ${ }^{c}$ Budapest University of Technology and Economics, Institute of Mathematics, Pf. 91, 1521 Budapest, Hungary \\ ${ }^{d}$ Central European University, Department of Economics, Nador u. 9, 1051 Budapest, Hungary \\ ${ }^{e}$ Corvinus University of Budapest, Fóvám tér 6-8, 1093 Budapest, Hungary
}

\begin{abstract}
We study a family of models of tax evasion, where a flat-rate tax finances only the provision of public goods, neglecting audits and wage differences. We focus on the comparison of two modeling approaches. The first is based on optimizing agents, who are endowed with social preferences, their utility being the sum of private consumption and moral utility. The second approach involves agents acting according to simple heuristics. We find that while we encounter the traditionally shaped Laffer-curve in the optimizing model, the heuristics models exhibit (linearly) increasing Laffercurves. This difference is related to a peculiar type of behavior emerging within the heuristics based approach: a number of agents lurk in a moral state of limbo, alternating between altruism and selfishness.
\end{abstract}

Keywords: Tax evasion, Tax morale, Agent-based simulation

JEL classification: $\mathrm{H} 26$

PsycINFO classification: 3020

\section{Introduction}

When we pay taxes we cooperate with our fellow citizens. This cooperation may lead to outcomes that, for all of us, are superior to those resulting from non-taxation, but in order to achieve these outcomes we have to incur immediate costs, as taxation amounts to shrinking our individual budget set. Cooperation has been one of the favorite problems of researchers in several disciplines. Economists traditionally approached the issue using tools borrowed from non-cooperative game theory, finding that many ideas can be shared with biologists who introduced evolutionary games as a closely related field. Later on, certain experimental games implicated psychology as well, and cooperation became interwoven with altruism and reciprocity, becoming a subject of behavioral economics. In experimental ultimatum, dictator or trust games, selfish individual rationality is consistently refuted, and some sort of "social behavior" prevails. Though in iterated experiments of public goods games the level of apparent benevolence is diminishing, it is not obvious whether this is due to learning or dissatisfaction with others' asocial behavior, see Fehr and Camerer (2004). It seems that people have other motives than maximizing their own incomes, since these experiments have such a simple structure that it is very unlikely that cognitive limitations could explain the altruism exhibited by participants. The experimental findings corroborate the important role of tax morale, including the impact of social relationships, as moral behavior may not be independent of the observation of our neighbors' acts, see Heinrich et al. (2004), Janssen and Ahn (2003), Cason et al. (2002).

The precise interpretations of altruism and reciprocity is a matter of controversy. Related phenomena have been given different names (e.g. reciprocal altruism, strong reciprocity). We may call it the "social animal" view of humanity, according to which people are bound to cooperate, being led by a disposition to confer material advantages onto

\footnotetext{
* Corresponding author

Email addresses: z.meder@maastrichtuniversity.nl (Zsombor Z. Méder), simonov@econ. core.hu (András Simonovits), janos.vincze@uni-corvinus.hu (János Vincze)
} 
others, without hoping for any immediate reward, or even without the sight of compensation. This is a disposition that may be deactivated if not reciprocated. The objects of our altruism can become thought of as unworthy to our generosity. It is even possible that non-cooperators incite our spite, and we wish to make them harm, even if this entails doing harm to ourselves. ${ }^{1}$

The psychological literature is split on the issue along several dimensions: whether reciprocity is the result of group or individual selection (see Gintis et al. (2008)), whether reciprocity is an adaptation or a by-product of an ancient adaptation that has become obsolete by today (Cosmides and Tooby (1997)). Here we focus on another point of contention: how to model reciprocity? Gintis et al. (2008) expresses the view that reciprocity can be handled in the framework of the beliefs, preferences and constraints model of human choice. (Examples include Fehr and Schmidt (1999) and Rabin (1993). However, there are some sharply different opinions on this issue. Citing Selten, Hertwig and Herzog (2009) refers to this social preference approach as "repair work". Gigerenzer and Selten (2002) puts forward the thesis that human social intelligence can be modeled in terms of boundedly rational fast and frugal heuristics, following Simon (1956). In the study of reciprocity the heuristics approach has been applied, for instance, in Delton et al. (2011).

In this paper we ask whether the social preference and the heuristics approaches can lead to different conclusions. If the answer is "yes", this may indicate a way to discriminate between the two modelling philosophies. We model reciprocity in a particular guise, taxation without enforcement. Our main result is that the two approaches produce some salient qualitative asymmetries.

Why is the taxation problem special? There is certainly no "instinct to pay taxes". To pay or not to pay taxes is a relatively recent problem for humankind, exhibiting certain features that distinguish it from other kinds of cooperation. A big problem with enforcing taxation is the ineffectiveness of individually punishing cheating. For the isolated individual, the only way to punish is to stop paying taxes, which has negligible effects on cheaters and non-cheaters alike. In the classical theory of taxation based on individual rationality, only centralized detection cum punishment of cheaters can make us comply. With instinctive altruism, taxes may be paid without persecuting cheaters, and in this paper we make the (unrealistic) assumption that noncompliance is never punished by society. This will help us differentiate between the two modeling approaches.

Models of tax compliance are closely related to public good provision problems. The taxation problem is different from other public good provision situations, because of the presence of a large number of mostly anonymously interacting agents. If public monitoring is costly, then it is a nontrivial issue to determine optimal audit probabilities and penalty schemes. The first mathematical analyses of Allingham and Sandmo (1972) and Yitzhaki (1974), modeled tax evasion as a gamble: for a given audit probability and a penalty proportional to the evaded tax, what share of their incomes do risk averse individuals report, when they have merely self-regarding preferences? Subsequent studies have discovered that the actual probability of audits and the penalty rate are insufficient to explain why citizens of some societies pay income taxes to such a high extent they do, again on the tacit assumption of self-regarding preferences.

Invoking some sort of social preferences is not uncommon in the tax evasion literature. This amounted to the introduction of tax morale, as in Frey and Weck-Hannemann (1984), and more recently in Lago-Penas and Lago-Penas (2010). To study the role of social preferences in isolation, Simonovits (2010) took tax morale as given, assumed a utility function which took into account the utility derived from the act of reporting along the utility derived from personal consumption. Taxes finance income redistribution as well as provision of public goods. The optimal report achieves a balance between the larger consumption due to lower report and the moral utility arising from higher report. The paper finds that higher tax morale induces greater income redistribution and net tax, financing a higher level of public expenditures. Traxler (2010) used a more refined model, making the moral utility dependent on the share of norm-followers: the moral utility from reporting is inversely related to the number of cheaters. He also incorporated the auditing and penalizing block from Allingham and Sandmo (1972). Now the existence of an equilibrium becomes an intricate problem, moreover, the case of multiple equilibria cannot be ruled out.

Another branch of the literature applied the heuristics approach to taxation problems, see Bloomquist (2006) or Szabó et al. (2009). These attempts are usually classified as agent-based models. Hokamp and Pickhardt (2010) is perhaps the most influential recent example. It uses four types of actors: rational agents, the equivalents of traditional selfish utility maximizers; moralists, who pay all their dues; erratics, who make errors, allowing for income

\footnotetext{
1 "By strong reciprocity we mean a propensity, in the context of a shared social task, to cooperate with others similarly disposed, even at personal cost, and a willingness to punish those who violate cooperative norms, even when punishing is personally costly."Gintis et al. (2008)
} 
overreporting; and emulators, who follow the behavior of their neighbors within a social network. Similar models are offered by Antunes et al. (2006), Frey and Torgler (2007) and Prinz (2010). Common to these models is that they do not assume social preferences as such. Agents are equipped with simple strategies (behavioral rules), and sometimes change their behavior by adopting strategies that perform better in terms of "individual fitness". These models usually focus on the problem of punishing tax evaders.

This paper analyzes tax evasion in the complete absence of audits and fines, similar too Simonovits (2010), but unlike most of papers cited above. Thus we can reformulate our main question as follows: what are the implications of different views on human behavior (social preferences or heuristics) in the Utopian world where nobody is forced to contribute to social funds? For the sake of simplicity, we neglect wage differences, as well as income redistribution, taxes finance the provision of public goods. Our tax system works with a flat rate without cash-back.

In the first set of models (Models A and B) agents maximize utility functions with social preferences. People are concerned with their own consumption, feel happiness if they contribute to the welfare of others, but became asocial if experience that their fellow-citizens are cheating. In model A, every worker knows the society's average previous reported income. In model B every worker has his own time-invariant neighborhood and he is able to observe his neighbors' previous tax reports. In both cases we investigate the existence of an equilibrium or multiple equilibria, and their stability. Under sensible parameterizations we encounter the traditional Laffer-curve, tax revenue first increases then decreases as the tax rate rises.

In our heuristics (or agent-) based model (model $\mathrm{C}$ ), income reporting is dichotomous, and agents make cueinduced decisions. They are willing to pay taxes, except when one or two cues indicate that the rest of society is not worthy of their generosity. These two cues are: feeling materially dissatisfied, and observing that the majority of their neighbors cheat. In such an environment these cues can be considered as the best thing to base reciprocation on. Material dissatisfaction is a (noisy) signal of large scale tax evasion, and by observing his neighbors one can judge the behavior of the whole society, though admittedly with a large sampling error. We allow people to differ in how they interpret these cues. In this model we tried to find parameters to replicate at least qualitatively the results obtained in the first two models. However, we have not been able to find non-monotonic Laffer-curves. This is the main result of the paper, and we interpret it as a possible way to discriminate between the two approaches to reciprocal altruism.

Laffer-curves have a natural shape in traditional economic models. At a tax rate of zero tax revenue is zero. too. At a tax rate of 1 self-regarding people do not work - or hide their income if they can - and tax revenue is again nil. By continuity there must be an interior tax rate where tax revenue is maximized. With reasonable social preferences in our social preferences model this familiar shape reappears, but with some interesting features. In our heuristics model, however, we have not been able to reproduce this. Though as the tax rate increases more and more agents opt for tax evasion, the increase in the number of evaders does not counterweight the effect of a larger tax rate. It is not impossible of course that one can set up a different model in the vein of our heuristics model where this result is overturned, but it is perhaps significant that we did not make assumptions deliberately in order to have a monotonically increasing Laffer-curve. What is the reason for this difference between the social preferences and heuristics approaches? We discover a type of agents who are marginal with respect to agent characteristics in the agent-based model. They lurk in an ethical state of limbo, dissatisfied with either paying or avoiding taxes. This kind of behavior can only arise in the heuristics approach. The existence of such agents diminishes the negative effect of tax rates on non-compliance, leading to a monotonic Laffer-curve within model C.

The structure of the paper is as follows. Section 2 presents models A and B, based on social preferences. The heuristics-based model $\mathrm{C}$ and simulation is presented in Section 3. The final section concludes.

\section{Social preferences}

This section formalizes the social preference approach. Here individuals maximize their morale-dependent utility functions. We consider two cases: the individual utility functions depend on the previous period income reports of the whole population or only on the average of neighbors.

\subsection{Model A: Full observation}

Let the number of workers be $I$. We will index workers as $i=1,2, \ldots, I$ and periods (say years) as $t=0,1,2, \ldots$. We assume that every worker earns the same amount, unity: $w=1$. Thus, there is no reason for income redistribution and the tax only finances the provision of public goods. 
Let $m_{i}$ be worker $i$ 's exogenous tax morale, let $v_{i, t}$ be his income report in period $t, v_{m} \leq v_{i, t} \leq 1$, where $v_{m}$ is the minimal report, $0 \leq v_{m}<1$. It is assumed that although the government knows that everybody earns a unity, it tolerates underreporting, insisting only on a minimal report.

In period $t$ the average reported wage is equal to

$$
\bar{v}_{t}=\frac{\sum_{i=1}^{I} v_{i, t}}{I}
$$

Let $\theta$ be a real number between 0 and 1 , the tax rate. Let $c_{i, t}$ denote worker $i$ 's consumption: $c_{i, t}=1-\theta v_{i, t}$. His traditional utility function is then $u\left(c_{i, t}\right)$. Let the moral utility function be $z\left(v_{i, t}, m_{i}, \bar{v}_{t-1}\right)$, which has three components: utility derived from his own report $v_{i, t}$, his exogenous morale $m_{i}$ and the previous average reported income $\bar{v}_{t-1}$. Finally let the per capita public expenditure be $X_{t}$, i.e. $X_{t}=\theta \bar{v}_{t}$, whose individual utility is $q\left(X_{t}\right)$.

Let us assume that $u(\cdot), z(\cdot, \cdot, \cdot)$ and $q(\cdot)$ are strictly increasing and strictly concave function. Worker $i$ 's utility is the sum of three terms:

$$
U_{i, t}=u\left(c_{i, t}\right)+z\left(v_{i, t}, m_{i}, \bar{v}_{t-1}\right)+q\left(X_{t}\right) .
$$

When maximizing $U_{i}$, the worker neglects the third term, since the effect of his decision on it is only marginal. In other words, in period $t$ worker $i$ reports such an income which maximizes his narrow utility:

$$
U_{i, t}^{*}\left(v_{i, t}\right)=u\left(1-\theta v_{i, t}\right)+z\left(v_{i, t}, m_{i}, \bar{v}_{t-1}\right) \rightarrow \max .
$$

In case of interior optimum,

$$
U_{i, t}{ }^{* \prime}\left(v_{i, t}\right)=-\theta u^{\prime}\left(1-\theta v_{i, t}\right)+z_{1}^{\prime}\left(v_{i, t}, m_{i}, \bar{v}_{t-1}\right)=0,
$$

where $z_{1}^{\prime}$ is the partial derivative of function $z$ with respect to the first variable.

In case of a corner solution, either

$$
v_{i, t}=v_{m} \quad \text { if } \quad U_{i, t}{ }^{* \prime}\left(v_{m}\right)=-\theta u^{\prime}\left(1-\theta v_{m}\right)+z_{1}^{\prime}\left(v_{m}, m_{i}, \bar{v}_{t-1}\right)<0,
$$

or

$$
v_{i, t}=1 \quad \text { if } \quad U_{i, t}{ }^{* \prime}(1)=-\theta u^{\prime}(1-\theta)+z_{1}^{\prime}\left(1, m_{i}, \bar{v}_{t-1}\right)>0 .
$$

The system's initial state is $\mathbf{v}_{0}=\left(v_{1,0}, \ldots, v_{I, 0}\right)$. The system is in an equilibrium $\mathbf{v}^{\mathrm{o}}=\left(v_{1}^{\mathrm{o}}, \ldots, v_{I}^{\mathrm{o}}\right)$ if starting the system from it, the system remains there. The system is called asymptotically stable if (i) for any real $\varepsilon>0$, there exists another real $\delta>0$, such that if the initial state is in the $\delta$-neighborhood of the equilibrium, it stays in the $\varepsilon$-neighborhood of the equilibrium and (ii) $v_{i, t}$ asymptotically converges to $v_{i}^{o}$.

We need to apply parameterized rather than general utility functions, c.f. Simonovits (2010):

$$
u_{i}\left(c_{i, t}\right)=\log c_{i, t}, \quad z\left(v_{i, t}, m_{i}, \bar{v}_{t-1}\right)=\bar{v}_{t-1} m_{i}\left(\log v_{i, t}-v_{i, t}\right), \quad q\left(X_{t}\right)=\omega \log X_{t},
$$

where $\omega>0$ is the efficiency parameter of the public expenditures. Note that the first and second factors of $z$ are endogenous and exogenous tax morales, while the third factor in parantheses increases with reported income $v_{i, t}$ for $v_{i, t}<1$ and decreases otherwise: there is no moral urge to overreport income.

Then the implicit difference equation of the optimal report is

$$
-\frac{\theta}{1-\theta v_{i, t}}+\bar{v}_{t-1} m_{i}\left(\frac{1}{v_{i, t}}-1\right)=0, \quad i=1,2, \ldots, I \text {. }
$$

Solving for $v_{t}$, we get:

$$
v_{t}=\frac{\theta+m_{i}(\theta+1) v_{t-1}-\sqrt{\left[\theta+m_{i}(\theta+1) v_{t-1}\right]^{2}-4 m_{i}^{2} \theta v_{t-1}^{2}}}{2 m_{i} \theta v_{t-1}} .
$$

\footnotetext{
${ }^{2}$ The exogenous tax morale has no direct economic meaning, it can only be inferred from indirect observations.
} 
Figure 1: The Laffer-curves under the social preferences approach for two different values of the tax morale parameter.

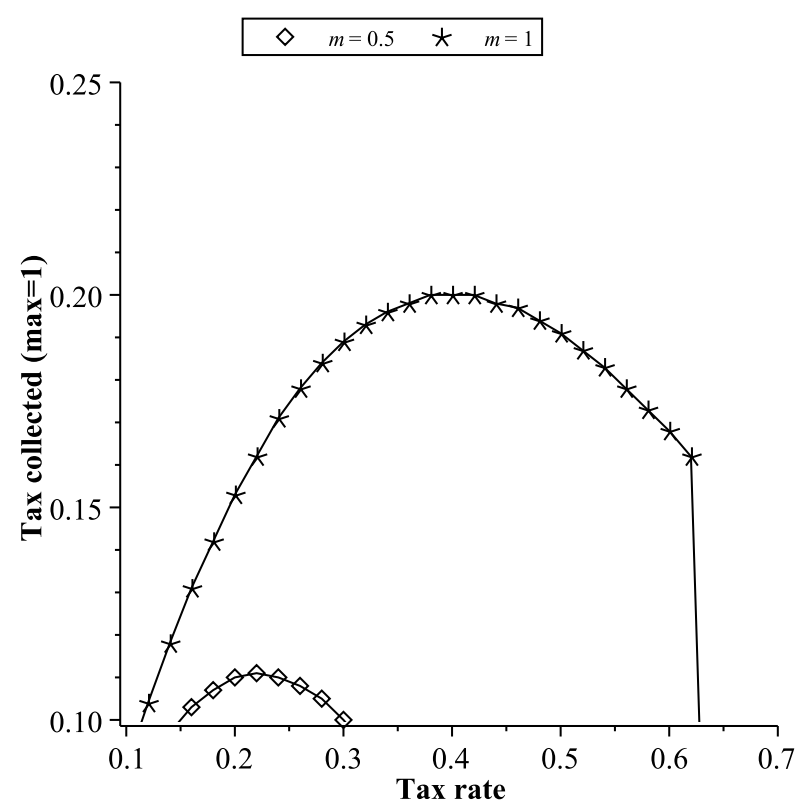

The equation of the equilibrium for the symmetric case $m_{i}=m$ is

$$
\frac{-\theta}{1-\theta v^{\mathrm{o}}}+v^{\mathrm{o}} m\left(\frac{1}{v^{\mathrm{o}}}-1\right)=0 .
$$

Then $c^{\mathrm{o}}=1-\theta v^{\mathrm{o}}, z^{\mathrm{o}}=v^{\mathrm{o}} m \log v^{\mathrm{o}}$ and $q\left(X^{\mathrm{o}}\right)=\omega \log \left(\theta v^{\mathrm{o}}\right)$.

It can be shown that the symmetric equilibrium of reports is the lower root of a quadratic equation:

$$
v^{\mathrm{o}}=\frac{1+\theta-\sqrt{(1-\theta)^{2}+4 \theta^{2} / m}}{2 \theta} .
$$

It is easy to see that the equilibrium report is an increasing function of the exogenous morale. It is more difficult to prove that the equilibrium report is a decreasing function of the tax rate.

When does an equilibrium exist? If $v_{m} \leq v^{0} \leq 1$, i.e.

$$
-\frac{\theta}{1-\theta v_{m} m}+v_{\mathrm{m}} m\left(\frac{1}{v_{\mathrm{m}}}-1\right)>0 \Leftrightarrow m>\frac{\theta}{\left(1-\theta v_{\mathrm{m}}\right)\left(1-v_{\mathrm{m}}\right) .}
$$

In principle, we can determine the socially optimal tax rate which maximizes $V$, or $U_{i}$ :

$$
U_{i}(\theta)=\log \left(1-\theta v^{\mathrm{o}}(\theta)\right)+v^{\mathrm{o}}(\theta) m\left(\log v^{\mathrm{o}}(\theta)-v^{\mathrm{o}}(\theta)\right)+\omega \log \left(\theta v^{\mathrm{o}}(\theta)\right)
$$

At this point we introduce the Laffer-curve, which relates the tax revenue to the tax rate:

$$
X(\theta)=\theta v^{\circ}(\theta) .
$$

It can be shown that the Laffer-curve is increasing for low tax rates and decreases for high rates assuming $m<$ $6+2 \sqrt{5} \approx 10.5$, see Fig. 1 .

Returning to the dynamics, note that after one step, the non-equilibrium path also becomes symmetric: $v_{i, t}=v_{t}$, because everybody will have the same optimization problem. Dropping the index $i$,

$$
F\left(v_{t-1}, v_{t}\right)=-\frac{\theta}{1-\theta v_{t}}+v_{t-1} m\left(\frac{1}{v_{t}}-1\right)=0
$$


The sufficient condition of local asymptotic stability is $\left|F^{\prime}\left(v^{o}\right)\right|<1$, where by implicit function theorem,

$$
\lambda=F^{\prime}\left(v^{\mathrm{o}}\right)=\frac{d v_{t}}{d v_{t-1}}=-\frac{F_{1}^{\prime}}{F_{2}^{\prime}} .
$$

Here $F_{1}^{\prime}$ and $F_{2}^{\prime}$ are the partial derivatives with respect to variables 1 and 2, respectively.

$$
F_{1}^{\prime}=m\left(\frac{1}{v^{\mathrm{o}}}-1\right) \quad \text { and } \quad F_{2}^{\prime}=\frac{-\theta}{\left(1-\theta v^{\mathrm{o}}\right)^{2}}+m \frac{1}{v^{\mathrm{o}}}
$$

Thus, the local stability condition is

$$
0<\theta<m\left(1-\theta v^{\mathrm{o}}\right)^{2}
$$

The issue of global stability requires further analysis.

We performed numerical simulations by experimenting with the parameter pairs $(m, \theta)$. First, we get rid of those pairs which generate optimal reports below the minimum or above 1 . For lower tax morale $(m=0.5)$, lower optimal tax rate (around $\theta=0.25$ ), for higher tax morale $(m=1)$, higher optimal tax rate (around $\theta=0.5)$ is obtained, see Table 1. It is remarkable that for low as well as high tax morales, the Laffer curve is already decreasing around the optimum: for $m=0.5$, raising the tax rate from 0.2 to 0.25 , the tax revenue drops from 0.11 to 0.1 ; while for $m=1$, raising the tax rate from 0.45 to 0.5 , the tax revenue drops from 0.198 to 0.191 , while the welfare increases. It seems paradoxical that the socially optimal report is a decreasing function of the exogenous tax morale.

Table 1: The impact of morale and tax rate in model $A$.

\begin{tabular}{rrrrrr} 
Morale & Tax Rate & Report & Tax paid & Utility & Expansion \\
$m$ & $\theta$ & $v$ & $X$ & $U$ & $\lambda$ \\
\hline 0.5 & 0.20 & 0.551 & 0.110 & -2.639 & -0.623 \\
0.5 & 0.25 & 0.438 & 0.110 & -2.604 & -0.776 \\
0.5 & 0.30 & 0.333 & 0.100 & -2.647 & -0.885 \\
\hline 1.0 & 0.45 & 0.439 & 0.198 & -2.396 & -0.809 \\
1.0 & 0.50 & 0.382 & 0.191 & -2.381 & -0.873 \\
1.0 & 0.55 & 0.329 & 0.181 & -2.384 & -0.919
\end{tabular}

\subsection{Model B: Limited Observation}

We now replace the assumption of global observability by local observability. Let $N_{i}$ be worker $i$ 's neighborhood (the index set of his neighbors), which is a small subset of the total index set $N=\{1,2, \ldots, I\}$. Let $\bar{v}_{i, t}$ be the average report of $i$ 's neighborhood in time $t$ :

$$
\bar{v}_{i, t}=\frac{\sum_{j \in N_{i}} v_{j, t}}{\left|N_{i}\right|},
$$

where $n_{i}=\left|N_{i}\right|$ is the number of neighbors, a small number relative to $I$, and in a symmetric case independent of $i$ and $n_{i} \ll I$. We assume that the system of neighborhoods is connected, i.e. any pair of individuals are connected by a chain of neighbors. Moreover, there is an integer $T,(T \leq I)$ that any pair is connected by a chain of length $T$.

Because of this generalization, we display several formulas again, in the general frame:

$$
U_{i}^{* \prime}\left(v_{i, t}\right)=-\theta u^{\prime}\left(1-\theta v_{i, t}\right)+z_{1}^{\prime}\left(v_{i, t}, m_{i}, \bar{v}_{i, t-1}\right)=0,
$$

where $z_{1}^{\prime}$ is the partial derivative of $z$ with respect to the first variable.

In case of corner solution, either

$$
v_{i, t}=v_{m} \text { if } U_{i}^{* \prime}\left(v_{m}\right)=-\theta u^{\prime}\left(1-\theta v_{m}\right)+z_{1}^{\prime}\left(v_{m}, m_{i}, \bar{v}_{i, t-1}\right)<0,
$$


or

$$
v_{i, t}=1 \text { if } U_{i}^{* \prime}(1)=-\theta u^{\prime}(1-\theta)+z_{1}^{\prime}\left(1, m_{i}, \bar{v}_{i, t-1}\right)>0 .
$$

The optimal report for interior optima is

$$
-\frac{\theta}{1-\theta v_{i, t}}+\bar{v}_{i, t-1} m_{i}\left(\frac{1}{v_{i, t}}-1\right)=0 .
$$

We often assume that the model is symmetric, i.e. if the individuals' indices are arbitrarily permuted, then the neighborhoods are also permuted correspondingly. Specifically, for every $i,\left|N_{i}\right|=n$ and $m_{i}=m$.

For the time being, we consider the simplest case.

Example. The workers are located on a circle: with the convention $I+1=1$ and $0=I$, let their neighbors be $N_{i}=\{i-1, i+1\}$. Then $\bar{v}_{i, t-1}=\left(v_{i-1, t-1}+v_{i+1, t-1}\right) / 2$, at an equilibrium $v_{i}^{\mathrm{o}}$ as in model $\mathrm{A}$

To study local stability, we shall return to the general case, where the entries of the matrix of the linearized equation $\mathbf{v}_{t}=A \mathbf{v}_{t-1}$ are as follows:

$$
a_{i j}= \begin{cases}F^{\prime}\left(v^{\mathrm{o}}\right) / n_{i} & \text { if } j \in N_{i}, \\ 0 & \text { otherwise. }\end{cases}
$$

Theorem 1. Under the stated assumptions, the symmetric equilibrium is locally asymptotically stable.

Proof. Due to symmetry, the row sums of $A$ are uniformly equal to $F^{\prime}\left(v^{0}\right)$. By the theory of Markov chains, the underlying Markov system is ergodic, its dominant characteristic root is equal to 1 . Hence the dominant characteristic root of $A$ is equal to $F^{\prime}\left(v^{0}\right)$.

In a separate paper, Garay, Simonovits and Tóth (2012) showed under quite general assumptions that the equilibrium is unique, symmetric and globally stable.

We can demonstrate by simulations that for symmetric initial states the difference between models A and B immediately disappears, though it survives for asymmetric initial states. The stability of model A also survives. We select the pair $m=1$ and $\theta=0.5$ and analyze the dynamics of asymmetric initial states for three agents. Let $x=1.3$, $v_{1,0}=x v^{\mathrm{o}}, v_{2,0}=v^{\mathrm{o}}$ and $v_{1,0}=v^{\mathrm{o}} / x$. It is sufficient to display the first six state vectors to see the preservation of stability, see Tab. 2 .

Table 2: Tax reports in model B also stabilize.

\begin{tabular}{rrrr} 
Period & Report 1 & Report 2 & Report 3 \\
$t$ & $v_{1}$ & $v_{2}$ & $v_{3}$ \\
\hline 0 & 0.497 & 0.382 & 0.294 \\
1 & 0.357 & 0.389 & 0.411 \\
2 & 0.392 & 0.383 & 0.377 \\
3 & 0.381 & 0.383 & 0.385 \\
4 & 0.383 & 0.382 & 0.382 \\
5 & 0.382 & 0.382 & 0.382
\end{tabular}

\section{The heuristics model}

\subsection{Overview}

Alternatives to economics-style theories of human decision-making stress the role of simple heuristics and the lack of integrated preferences. In this framework people have available a set of heuristics (decision rules), and a mechanism for selecting a decision rule (see for instance Gigerenzer and Selten (2002)). In our model we assume the existence of two working heuristics. 
1. Pay taxes if you are satisfied with your lot, and do not pay if you are dissatisfied.

2. Pay taxes if most of your neighbors pay, and do not pay if most of them do not pay.

The first heuristic is based on a cue that is close to the concept of utility. Agents consume private goods and enjoy the fruits of public good provision. These two sources of utility manifest themselves in a feeling of satisfaction or dissatisfaction. We retain the traditional assumption of monotonicity, higher consumption of both private and public goods makes it more likely that agents' utility exceeds their satisfaction threshold. This property of the model has close resemblance to the concept of satisficing (Simon (1956)). Agents are heterogeneous, in the sense that their thresholds are different. For a given level of consumption some people are satisfied, while others are not. The cue of the first heuristic can serve for detecting cheating by other members of the society, or by the government. When there are many cheaters, dissatisfaction is one of the possible indicators of unsocial behavior by others.

The second heuristic is the well-established imitation heuristic adapted to our problem. Imitation seems to be a general purpose heuristic, or a basic constituent of the human mind (see Meltzoff (1988) who proposed the expression "homo imitans" for our race). However, in the taxation context it can also be deemed as a way of detecting cheaters. It relies on direct evidence on cheating, but this evidence is imperfect as one's neighbors (i.e. people whose tax paying behavior one can observe) are only a small sample of the whole population.

We believe that both heuristics are sensible, since both can be looked at as proxy mechanisms for detecting and punishing non-cooperators, and it is difficult to see what other detection cues may exist. As a method of punishment tax-cheating is not very effective, but the only way of retribution, short of beating up confirmed cheaters. Also this is a sweet one, since utility - ceteris paribus - increases after stopping tax payment.

These two decision rules can be in conflict. In the traditional, preference based approach such a problem cannot arise because - according to the parlance of the psychological literature - preferences are "integrated". In our framework we must postulate some conflict-resolving mechanism, a meta-heuristic. Of the possible reasonable metaheuristics we consider two:

1. Pay taxes whenever at least one (first-level) heuristic suggests tax-paying.

2. Pay taxes only if both of the (first-level) heuristics suggest tax-paying.

Both meta-rules seem intuitively plausible, therefore we suppose that they are distributed in some proportion across the population.

\subsection{Specification}

We construct a simple agent-based model to analyze the way local interactions foster or hinder the spreading of tax evasion. There are $I$ agents, having uniform real income (measured in terms of the private good) in each period $t$, which is normalized to 1 . The individual budget constraints are:

$$
c_{i t}+v_{i t}=1,
$$

with $c_{i t}$ denoting private consumption, and $v_{i t}$ representing taxes paid. Agents have identical, linear utility functions.

$$
u_{i t}=c_{i t}+\omega X_{t}
$$

where

$$
X_{t}=\frac{\sum_{i=1}^{I} v_{i t}}{I}
$$

represents the service of the public good enjoyed by an agent. We report only results with linear utility, as outcomes for logarithmic utility were qualitatively similar. The numerator is the amount of the public good financed by tax. Parameter $\omega$ introduced to capture the efficiency of the public sector. Thus if $\omega>1$, then public spending is efficient and the socially optimal outcome would involve a maximal tax rate with full adherence to the taxpaying norm. On the other hand if $\omega<1$, taxation is wasteful, and the social optimum would entail a zero tax rate. 
Let $0<\theta<1$ be the tax rate. The tax behavior of each agent is represented by a binary variable:

$$
v_{i t}=0 \text {, }
$$

if agent $i$ does not pay taxes in period $t$, and

$$
v_{i t}=\theta
$$

if he does.

Each agent $i$ is characterized by a real number $u_{i}$ giving his frustration threshold in terms of utility. We say that an agent is "internally" frustrated in $t$ if $u_{i, t-1}<u_{i}$. Also, each agent $i$ has a neighborhood $N_{i} \subset N$, interpreted as the set of acquaintances whose behavior is observable by $i$. Agents observe their neighbor's decisions. Let $m_{i, t}$ represent the share of tax evaders among agent $i$ 's acquaintances. Then, this agent is "externally" frustrated in $t$ if $m_{i, t-1}>0.5$. The two cues of internal and external frustration nail down the heuristics mentioned above.

Tax behavior, is, in the end, determined through one of the meta-rules. If agent $i$ is following the first meta-rule pay taxes if any of the heuristics suggest so - we will say that he is a default taxpayer.

$$
v_{i t}= \begin{cases}\theta & \text { if } u_{i, t-1} \geq \bar{u}_{i} \text { or } m_{i, t-1}<0.5, \\ 0 & \text { otherwise. }\end{cases}
$$

For an agent following the second meta-rule, we say that he is a default cheater.

$$
v_{i t}= \begin{cases}\theta & \text { if } u_{i, t-1} \geq \bar{u}_{i} \text { and } m_{i, t-1}<0.5, \\ 0 & \text { otherwise. }\end{cases}
$$

Variable $v_{i t}$ is also the (partly) public state of agent $i$ in period $t$, inasmuch as those people whose neighborhoods include $i$ can observe it. The agent characteristic $\left(\bar{u}_{i}\right)$ is time invariant, and non-observable. To diminish the significance of the initial pattern of tax compliance, we also introduced "noise" in the system. That is, each period agents with a fixed probability switch from tax evasion to compliance or vice-versa, making random "mistakes".

Next we present the skeleton of the algorithm used to run the simulations. ${ }^{3}$ Then, we describe the choice of parameters for the runs, and finally, we present our main results.

1. Create $I$ agents, $s_{0}$ of whom are default cheaters; they will start by cheating in the first round.

2. Assign satisfaction levels $u_{i}$ to agents according to a normal distribution with mean of $\mu_{u}$ and standard deviation of $\sigma_{u}$.

3. Determine the neighborhoods of the agents, $N_{i} \subset N$, depending on parameter $d$.

4. Calculate the amount of public goods $(X)$ according to the tax behavior of each agent, the tax rate $\theta$ and public efficiency $\omega$.

5. Specify the utilities $\left(u_{i, t}\right)$ of agents, by adding their utility gained from private and public consumption.

6. Start a new period, let $t=t+1$.

7. Update the strategies $v_{i, t}$ of agents.

8. Apply noise to the agents' strategies.

9. Iterate on 5, 6, 7 and 8 until the system becomes stationary.

We shortly discuss the chosen range of values for these variables and their interpretations below.

1. The number of agents was $I=1000$ for each run. The share of default cheaters $s_{0}$ was varied from 0 to 1 .

2. The mean of satisfaction levels $\mu_{u}$ was set between 0.5 and 1.5. A lower value represents a "richer" society where the ratio of income to consumer desires is high. The standard deviation $\sigma_{u}$ could take on three possible values: $0,0.25$ and 0.5 , the first value inducing a limit scenario where every agent had identical aspiration level.

3. Agents were located on a circle. The previous and next $d \in\{1,2, \ldots, 10\}$ agents were considered parts of their neighborhood; agents could observe whether these were tax avoiders or payers this period. This parameter attempts to capture social proximity. Higher social proximity implies that agents have access to more information, a larger sample of the total population concerning tax behavior.

\footnotetext{
${ }^{3}$ The algorithm was implemented in the NetLogo language.
} 
4. The tax rate was changed between $0 \%$ and $100 \%$ in steps of 5\%. Public efficiency $\omega$ was chosen to be very low (0.4), low (0.7), average (1), high (1.3) or very high (1.6).

6. We ran the simulations until the share of tax evaders stabilized. The time frame of $t=300$ periods proved to be sufficient for reaching a stochastically stationary state for all parameter combinations.

8. We fixed the noise parameter at $1 \%$.

\subsection{Results}

In total, 173, 250 runs were executed, covering all parameter combinations. The variable of principal interest was the share of tax evaders in the final population, defined as the the average share of tax evaders in the population in the last 50 periods.

Since being a default cheater or default taxpayer does not change over time, and this property of our agents is crucial in determining their tax behavior, the correlation between the share of default cheaters and the average share of tax evasion in the steady state is very high at 0.8 . This implies that most of the variance in the final share of cheaters can be explained by the share of default cheaters. Moreover, a linear estimate of the effect of default cheaters gives a slope prameter of 1.07, which is not significantly different from $1(p<0.01)$. Therefore, we decided to focus our investigation on the relationship between our parameters (satisfaction levels, social proximity, the tax rate and public efficiency) and the difference between the final share of cheaters and default cheaters. We will dub the latter as "bias in evasion" and quote it in percentage points. Note that a positive value for this variable means that the frequency of tax evasion in the long run is higher than its share in the initial state. The average bias in evasion across all runs was slightly negative, -5.9 .

Partial and cross effects. Satisfaction levels had a linear effect on the bias in evasion. Based on a linear estimate, a rise of 0.1 in average satisfaction levels increased bias in evasion by 3.8 percentage points. Unsurprisingly, societies that are "rich" (compared to the desires of their citizens) have an easier time in dealing with tax evasion: for a satisfaction level of 0.5 , average bias in evasion is -25 . However, with a very high share of default tax evaders $(>80 \%)$, the problem of tax evasion might still be persistent. We have also found that uniformity in desire helps dealing with evasion; smaller standard deviatons of satisfaction levels lead to lower bias in evasion.

Neighborhood size also has a monotonic, but non-linear relationship on bias in evasion. With $d=1$, i.e. everybody has only two neighbors, bias in evasion is -16 , whereas with $d=10$ it increases to -2 . Contrary to intuition, when social relations are intense, tax evasion is much more difficult to get rid of. It should be mentioned that cohesion has diminishing returns as far as change in evasion is concerned.

Public efficiency is again in a linear relationship with evasion. An average increase of 0.1 increases decreases biase in evasion by 0.8 . This is a small effect compared to those of satisfaction levels and social cohesion.

Finally, the tax rate is in a complex relationship with the bias in evasion, see Fig. 2. Changing the tax rate from $5 \%$ to $25 \%$ might even be beneficial for tax evasion; and there are other intervals ([45\%,55\%] and [85\%,100\%]) on which the average effect of the tax rate is extremely small.

We find that average satisfaction levels, neighborhood size and public efficiency do not interact. On the other hand, low tax rate helps reduce evasion when satisfaction levels are low, and increases it when they are high. A plausible reason for this effect is that high satisfaction levels also imply that the private procurement of goods could well be inadequate, so a "poor" society needs more governmental spending (and thus higher taxes) to make taxpayers sufficiently satisfied.

A similar interaction emerges between social efficiency and the tax rate: a low tax rate is best (in terms of tax evasion) for low social efficiency (Fig. 3). With social efficiency increasing above unity, higher tax rates become more attractive. The differential effect increases gradually until a tax rate of 0.7 , and changes very little afterwards.

An interesting property of our simulations is that certain agents have mixing behavior, whereby they switch from paying taxes to tax evasion every other turn. Imagine a default cheater is in a taxpayers dominated environment. He pays his taxes one turn, but this may sent him below his utility threshold, As he finds himself unhappy he turns to tax evasion. But suppose that by evading tax, he is now again over his utility threshold; and since his environment contains mostly taxpayers, the combination of external and the internal heuristics now induce him to pay his taxes again. A similar story can be told of some default taxpayers in a neighborhood of tax evaders. Overall, the share of agents with such mixing behavior is small but nonnegligable: over all runs, their share in the population is $7.9 \%$. The behavior of these „marginal” agents is sensitive to changes in satisfaction levels and social efficiency, since such 
Figure 2: The effect of the tax rate on bias in evasion.

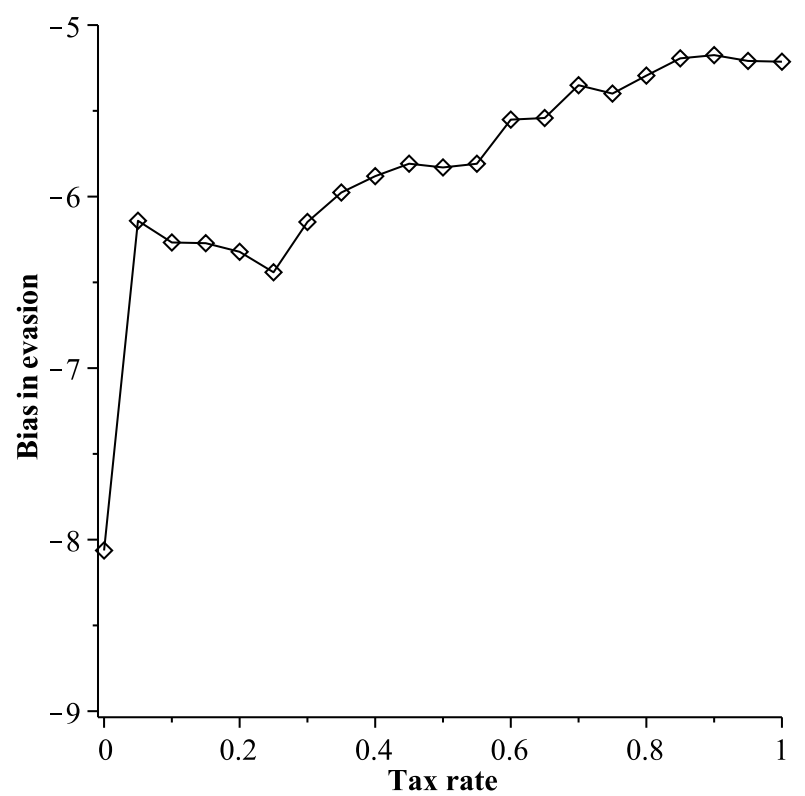

Figure 3: The relationship between the tax rate and bias in evasion for various values of social efficiency.

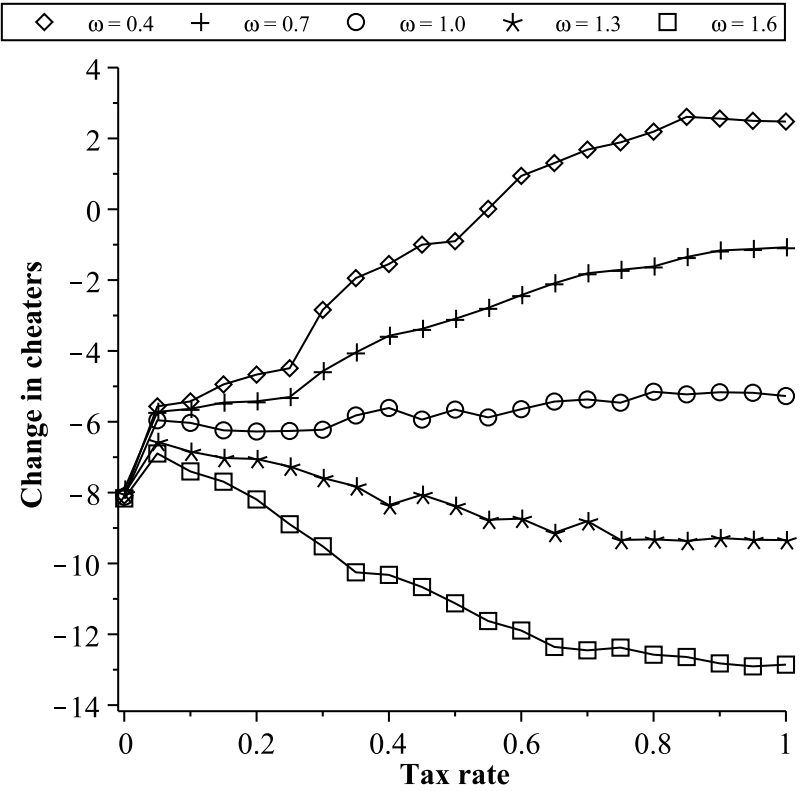




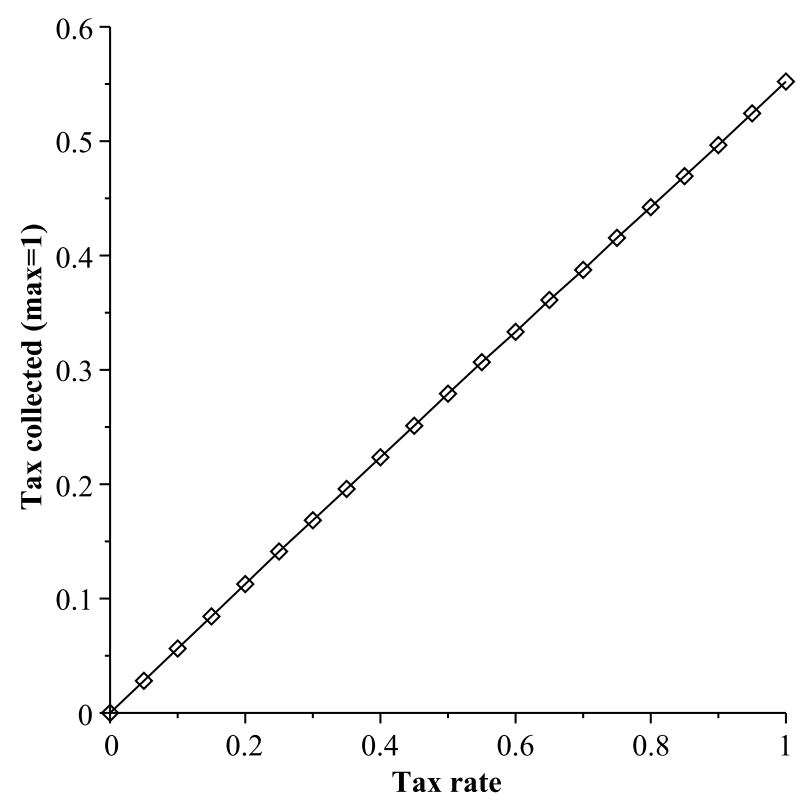

effects might push their utility permanently over or under their thresholds. However, increasing the tax rate does not necessarily alter mixing behavior. To see this, suppose that at a certain tax rate an agent is a switcher. Disregarding the rise in the level of the public good, increasing the tax rate will make a switcher even more dissatisfied when he pays taxes, but in these periods he was dissatisfied anyway. Obviously, in the periods when a switcher does not pay taxes, he is not affected by the tax rate except indirectly, through the public good provided by others paying their taxes. Therefore, any impact of the tax rate on switchers can only come through the public good.

Laffer-curves. We now turn to inspecting Laffer-curves (i.e the relationship between the tax rate and tax revenues) within our model. Although, as we have seen, the relationship between bias in evasion and the tax rate is positive, this effect is not strong enough to offset the higher tax rate effect. Therefore, as Fig. 4 shows, tax revenue increases monotonically with the tax rate, and the relationship is very close to linear. This effect is qualitatively replicated when fixing one or more of the parameters analyzed above. Lower average satisfaction levels, higher social uniformity, weaker social cohesion and greater efficiency all lead to steeper, but nonetheless approximately linear Laffer-curves.

This result stands in sharp contrast with that of the social preferences model. We interpret it as a possible discriminating feature: optimizing behavior even with social preferences can produce too high tax rates, i.e too high from the point of view of government revenue, whereas non-optimizers with "unselfish" motives may sacrifice themselves by paying taxes even at very high rates.

\section{Conclusion}

This paper analyzed taxation models without audits and fines, neglecting wage differences, and assuming that taxes finance only the provision of public goods. We focused on the differences between two modelling approaches: the social preferences and the heuristics views, each taking for granted that humans possess conditionally altruistic motives. However, they differ in the way the behaviour stemming from these motives is formalized. Is this difference essential or just a matter of taste?

In the social preferences models we encounter the traditionally shaped Laffer-curve, tax revenue first increases then decreases as the tax rate rises. On the other hand, in the heuristics models we meet (linearly) increasing Laffercurves. We discover agents with a strange behavioral pattern; these "marginal" agents use mixed strategies over time, 
alternating between paying and avoiding taxes, as if they regretted each action the instant they performed it. Though even in this model higher tax rates induce more evasion the relationship is linear due to the smoothing effect of regretful agents. Thus in the heuristics models with non-optimizing agents tax rates are never "too high". This conclusion is valid even with low social efficiency, which would mean that non-optimizing agents can be remorselessly exploited by inefficient or malevolent governments.

Thus, the two modeling approaches seem to be essentially different, leading to antithetic conclusions. How to test the two theories against each other remains an open question.

\section{References}

Allingham, M. G. and Sandmo, A. (1972). Income tax evasion: a theoretical analysis. Journal of Public Economics 1, $323-338$.

Antunes, L. B., Urbano J., Moniz P. and Roseta-Palma, L. C. (2006). Tax compliance in a heterogeneous multi-agent society. Multi-Agent-Based Simulations VI, Springer, 147-161.

Bloomquist, K. M. (2006). A comparison of agent-based models of income tax evasion. Social Science Computer Review 24/4, 411-425.

Cason, T. N., Saijo, T. and Yamato, T. (2002). Voluntary participation and spite in public good provision experiments. Experimental Economics 5, $133-153$.

Cosmides, L. and Tooby, J. (1997). Evolutionary psychology: a primer. Retrieved December 15, 2011 from http://www.psych.ucsb.edu/research/cep/primer.html.

Delton, A.W., Krasnow, M.M., Cosmides, L. and Tooby, J. (2011). The evolution of direct reciprocity under uncertainty can explain human generosity in one-shot encounters. Proceedings of the National Academy of Sciences of the United States of America 108/32, 13335-13340.

Fehr, E. and Camerer, C. F. (2004). Measuring social norms and preferences using experimental games: A guide for social scientists. In: Heinrich et al. (2004), 55-96.

Ernst, F. and Schmidt, K.M. (1999). A theory of fairness, competition, and cooperation. Quarterly Journal of Economics, 114/3, 817-868.

Frey, B. S. and Torgler, B. (2007). Tax morale and conditional cooperation. Journal of Comparative Economics 35/1, $136-159$.

Frey, B. S. and Weck-Hannemann, H. (1984). The hidden economy as an 'unobserved' variable. European Economic Review 26/1-2, 33-53.

Garay, B., Simonovits, A. and Tóth, J. (2012). Local interaction in tax evasion. Economics Letters (forthcoming).

Gigerenzer, G. and Selten, R. [eds.] (2002). Bounded rationality: the adaptive toolbox. MIT Press.

Gintis, H., Henrich, J., Bowles, S., Boyd, R. and Fehr, E. (2008). Strong reciprocity and the roots of human morality, Social Justice Research 21, 241-253.

Heinrich, J., Boyd, R., Bowles, S., Camerer, C. F., Fehr, E. and Gintis, H. (2004). Foundations of human sociality. Oxford University Press, Oxford. Hertwig, R. and Herzog, S. M. (2009). Fast and frugal heuristics: Tools of social rationality. Social Cognition, 27, 661-698.

Hokamp, S. and Pickhardt, M. (2010). Income tax evasion in a society of heterogeneous agents - evidence from an agent-based model. Institute of Spatial and Housing Economics, Working Paper 201035, University of Münster.

Janssen, M. A. and Ahn, T. K. (2003). Adaptation vs. anticipation in public-good games. Annual meeting of the American Political Science Association, Philadelphia.

Lago-Penas, I. and Lago-Penas, S. (2010). The determinants of tax morale in comparative perspective: evidence from European countries. European Journal of Political Economy 26, 441-453.

Meltzoff, A.N. (1988): The human infant as homo imitans. In: Zentall, T. R. and Galef, B. G. [eds.]. Social learning: psychological and biological perspectives. Psychology Press, 321-347.

Prinz, A. (2010). A moral theory of tax Evasion, Working Paper, University of Münster.

Rabin, M. (1993). Incorporating fairness into game theory and economics. American Economic Review 83/5, 1281-1302.

Simon, H. A. (1956). Rational choice and the structure of the environment, Psychological Review 63/2, 129-138.

Simonovits, A. (2010). Tax morality and progressive wage tax. Discussion Paper 5, Institute of Economics, Hungarian Academy of Sciences.

Szabó., Gulyás L. and Tóth I. J. (2009). The change in the share of tax evasion: estimation with the help of agent-based tax evasion simulator

TAXSIM. In: Semjén and Tóth [eds.]: Hidden economy: undeclared employment and income sheltering - government measures and the reactions of economic actors (in Hungarian). Institute of Economics, Hungarian Academy of Sciences, 65-83.

Traxler, Ch. (2010). Social norms and conditional cooperative taxpayers. European Journal of Political Economy 26, 89-103.

Yitzhaki, S. (1974). Income tax evasion: a theoretical analysis. Journal of Public Economics 3, 201-202. 
Discussion Papers published in 2011

Mihályi Péter: Utolérési kísérletek Magyarországon, 1870-2030. MT-DP 2011/ 1

Zsolt Darvas - J ean Pisani-Ferry: The Threat of 'Currency Wars': A European Perspective. MT-DP 2011/ 2

Zsolt Darvas: Beyond the Crisis: Prospects for Emerging Europe. MT-DP 2011/ 3

Barnabás M. Garay - András Simonovits - János Tóth: Local Interaction in Tax Evasion. MT-DP 2011/ 4

Maria Csanadi: Varieties of System Transformations and Their Structural Background Based on the IPS Model. MT-DP 2011/ 5

Mária Lackó: The Poor Health Status of the Hungarians; Comparative Macro-Analysis of the Likely Explanatory Factors on Hungarian and Austrian Data, 1960-2004. MT-DP 2011/ 6

Fazekas Károly: Közgazdasági kutatások szerepe az oktatási rendszerek fejlesztésében. MT-DP 2011/ 7

Gábor Kézdi - Gergely Csorba: Estimating the Lock-in Effects of Switching Costs from Firm-Level Data. MT-DP 2011/ 8

Antal-Pomázi Krisztina: A kis- és középvállalkozások növekedését meghatározó tényezők A különböző finanszírozási formák hatása a vállalati növekedésre. MT-DP 2011/ 9

Zsolt Darvas - J ean Pisani-Ferry - André Sapir: A Comprehensive Approach to the EuroArea Debt Crisis. MT-DP 2011/ 10

András Simonovits: International Economic Crisis and the Hungarian Pension Reform. MT-DP 2011/ 11

András Simonovits: The Mandatory Private Pension Pillar in Hungary: An Obituary. MTDP 2011/ 12

Horn Dániel: Az oktatási elszámoltathatósági rendszerek elmélete. MT-DP 2011/ 13

Miklós Koren - Márton Csillag: Machines and machinists: Capital-skill complementarity from an international trade perspective. MT-DP 2011/ 14

Áron Kiss: Divisive Politics and Accountability. MT-DP 2011/ 15

Áron Kiss: Minimum Taxes and Repeated Tax Competition. MT-DP 2011/ 16

Péter Csóka - Miklós Pintér: On the Impossibility of Fair Risk Allocation. MT-DP 2011/ 17

Gergely Csorba - Gábor Koltay - Dávid Farkas: Separating the ex post effects of mergers: an analysis of structural changes on the Hungarian retail gasoline market. MT-DP 2011/ 18

Helga Habis and P. Jean-Jacques Herings: Core Concepts for Incomplete Market Economies. MT-DP 2011/ 19

Helga Habis and P. J ean-J acques Herings: Transferable Utility Games with Uncertainty. MT-DP 2011/ 20

Valentiny Pál: Árukapcsolás és csomagban történő értékesítés: jogesetek és közgazdasági elmélet. MT-DP 2011/21

Seres Antal - Felföldi János - Kozak Anita - Szabó Márton: Termelői szervezetek zöldséggyümölcs kisárutermelóket integráló szerepe a nagy kereskedelmi láncoknak történő értékesítésben. MT-DP 2011/22 
Tamás Fleiner - Balázs Sziklai: Notes on the Bankruptcy Problem: an Application of Hydraulic Rationing. MT-DP 2011/ 23

Zoltán Hermann - Dániel Horn: How inequality of opportunity and mean student performance are related? A quantile regression approach using PISA data. MT-DP $2011 / 24$

Dávid Csercsik - László Á. Kóczy: Externalities in the games over electrical power transmission networks. MT-DP 2011/ 25

Dóra Balog: Capital allocation in financial institutions: the Euler method. MT-DP 2011/26

Zsolt Darvas - Valentina Kostyleva: Fiscal and Monetary Institutions in Central, Eastern and South-Eastern European Countries. MT-DP 2011/ 27

Jing Dang - Max Gillman - Michal Kejak: Real Business Cycles with a Human Capital Investment Sector and Endogenous Growth: Persistence, Volatility and Labor Puzzles. MT-DP 2011/ 28

László Á. Kóczy - Miklós Pintér: The men who weren't even there: Legislative voting with absentees. MT-DP 2011/ 29

Békés Gábor - Koren Miklós - Zsohár Péter: Benzinárak földrajzi meghatározása. MT-DP 2011/30

Maria Csanádi: Adaptation pressures during global decline on system transformation and its spatial consequences in China. MT-DP 2011/31

Péter Biró-Gethin Norman: Analysis of Stochastic Matching Markets. MT-DP 2011/ 32

Zsolt Darvas: Debt restructuring in the euro area: a necessary but manageable evil? MT-DP 2011/33

Berthold Herrendorf - Richard Rogerson - Akos Valentinyi: Two Perspectives on Preferences and Structural Transformation. MT-DP 2011/ 34

Róbert Somogyi - János Vincze: Price Rigidity and Strategic Uncertainty - An Agent-based Approach. MT-DP 2011/35

Karsai Judit: A kockázati tőkeipar két évtizedes fejlődése Magyarországon. MT-DP 2011/ 36

András Simonovits: Higher tax morale implies a higher optimal income tax rate. MT-DP 2011/ 37

Judit Katona-Kovács - Chris High - Gusztáv Nemes: Importance of Animation Actions in the Operation of Hungarian Local Action Groups. MT-DP 2011/ 38

Péter Biró - Flip Klijn: Matching with Couples: a Multidisciplinary Survey. MT-DP 2011/39

Hermann Zoltán: A tanári jellemzők hatása a tanulói teljesítményre Európai eredmények a TIMSS adatok alapján. MT-DP 2011/ 40

Semjén András: A tandíj közgazdaságtana - Szakirodalmi áttekintés. MT-DP 2011/41

Peter Biró - Walter Kern - Daniel Paulusma: Computing solutions for matching games. MT-DP 2011/ 42

Békés Gábor - Halpern László - Muraközy Balázs: A magyar külkereskedő vállalatok. MTDP 2011/ 43

Discussion Papers are available at the website of Institute of Economics Hungarian Academy of Sciences: http:// econ.core.hu 